\title{
Hubungan obesitas pada orangtua dengan terjadinya obesitas pada anak remaja SMA di Kota Denpasar, Provinsi Bali
}

\section{Theodorus Onesiforus Gozali ${ }^{1}$, Made Ratna Saraswati ${ }^{2}$}

1Program Studi Pendidikan Dokter Fakultas Kedokteran Universitas Udayana

2Bagian/ SMF IImu Penyakit Dalam, FK Universitas Udayana/ RSUP Sanglah

Tanggal diterima : 16 Maret 2017 Tanggal Disetujui : 2 Mei 2017

Tanggal Diterbitkan : 10 Mei 2017
Tujuan: Studi ini bertujuan melakukan pencarian prevalensi obesitas orangtua, anak, serta hubungan obesitas orangtua terhadap obesitas anak remaja sekolah menengah atas (SMA) di Denpasar tahun 2015.

Metode: Penelitian observasional ini memiliki rancangan studi potong lintang dengan melakukan pengambilan data anak sekolah menengah atas dibeberapa sekolah di Denpasar. Secara acak dipilih sampel yang dapat mewakili Denpasar. Kuesioner dibagikan dan diminta untuk diisi oleh siswa-siswi. Dilanjutkan dengan pengukuran berat badan, tinggi badan, lingkar pinggang, maupun lingkar lengan atas. Pengukuran dilakukan pada siswa-siswi maupun kedua orangtuanya.

Hasil: Dari 298, 188 (63,09\%) yang dapat diambil menjadi data. Prevalensi obesitas orangtua 40,96\% dan obesitas anak sekolah menengah atas 15,4\%, di Denpasar tahun 2015. Analisis data menunjukkan bahwa terdapat hubungan antara status nutrisi atau gizi ibu ditinjau dari indeks massa tubuh dengan lingkar pinggang atau lingkar lengan atas terhadap status gizi anak sekolah menengah atas di Denpasar. Hubungan dari status gizi pada jumlah orangtua obesitas berdasarkan indeks massa tubuh dengan status gizi pada anak sekolah menengah atas di Denpasar pada 2015 juga ditemukan, nilai $p<0,05$.

Simpulan: Terdapat hubungan obesitas orangtua ditinjau dari indeks massa tubuh terhadap obesitas anak sekolah menengah atas di Denpasar pada tahun 2015. Adanya kelemahan di dalam penelitian membuat perlu dilakukannya penelitian lebih lanjut dengan topik ini, dengan sampel lebih besar dan memperhatikan faktor-faktor perancu penelitian.

Katakunci: Obesitas, orangtua, anak remaja sekolah menengah atas, Denpasar, 2015

Aim: This study aimed to explore the prevalence of obesity in parents, children, and connection between obesity on parents and senior high school teenagers in Denpasar in 2015.

Methods: This observasional research has cross-sectional design as its study, with purposive random sampling method to take data randomly to describe the population. Questionnaire spread and students asked to fill it. Continued with measurement of height, weight, waist cricumference, and arm circumference of students and their parents.

Results: From 298 questionnaires, only 188 (63.09\%) used as data. Parental prevalence of obesity was $40.96 \%$, while student was $15.4 \%$ in Denpasar, 2015. Data analyzed showed relation between nutritional states of mother, looked from the body mass index and waist circumference (WC) or arm circumference (AC) with students' nutritional state, also relation between nutritional states of number of parents that are obese based on body mass index with nutritional states of students, $p<0.05$.

Conclusion: There was association between obesity in parents with the obesity in senior high school teenagers in Denpasar in 2015, based on their body mass index. Another advance researches in the future regarding this topic is needed due to weaknesses of the study, with greater number of samples and more attention to the confounding factors in this study.

Keywords: Obesity, parents, senior high school teenager, Denpasar, 2015

\section{PENDAHULUAN}

Obesitas termasuk penyakit yang berkaitan dengan metabolisme tubuh. Salah satu alat ukur yang paling umum digunakan untuk menentukan status obesitas adalah indeks massa tubuh (IMT). Umumnya pada orang dewasa, indeks massa tubuh memiliki jangkauan dari $25 \mathrm{~kg} / \mathrm{m}^{2}$ hingga $29 \mathrm{~kg} /$ $\mathrm{m}^{2}$ untuk golongan berlebihan berat badan dan obesitas jika nilainya sudah mencapai $30 \mathrm{~kg} / \mathrm{m}^{2}$ atau lebih berdasarkan kriteria internasional. Kriteria Asia-Pasifik menyatakan seseorang tergolong obesitas ketika indeks massa tubuh mencapai $25 \mathrm{~kg} / \mathrm{m}^{2}$ atau lebih., ${ }^{1,2}$

Menurut data yang diperoleh oleh world health organization (WHO) dalam world health statistic (WHS) tahun 2012, prevalensi penderita obesitas dari tahun 1980 hingga 2008 meningkat kurang lebih dua kali lipat secara global. ${ }^{3}$ Organization of Economic Co-operation and Development (OECD) 
menemukan bahwa pada tahun 2010 dan setelahnya, angka kejadian obesitas di Indonesia adalah 2,4\%, dari 2,4\% ini, 3,6\% perempuan dan $1,1 \%$ lelaki dibandingkan populasi dunia. Selain itu, riset kesehatan dasar (RISKESDAS) tahun 2013, prevalensi obesitas orang dewasa (diatas 18 tahun) kurang lebih $15,4 \% .{ }^{4,5}$ Sedangkan di Bali, riset kesehatan dasar tahun 2007 melaporkan bahwa Bali menjadi salah satu provinsi yang memiliki anak sekolah (6-14 tahun), baik perempuan maupun lelaki dengan prevalensi obesitas di atas prevalensi nasional. Pada anak di atas 15 tahun juga memiliki prevalensi obesitas melebihi prevalensi nasional. ${ }^{6}$

Komplikasi obesitas dapat dipicu sejak terjadinya obesitas pada remaja. Komplikasi yang terjadi dapat berhubungan dengan tekanan darah, kolesterol, tingkat trigliserida, dan diabetes, sehingga menjadi faktor meningkatnya risiko jantung koroner, stroke iskemik, diabetes mellitus tipe 2 dan penyakit metabolisme lainnya.?

Kurangnya aktivitas fisik, pola makan tidak seimbang, maupun riwayat orangtua mengalami obesitas dapat menjadi penyebab obesitas. Riwayat orangtua obesitas menjadi faktor pemicu yang cukup besar untuk terjadinya obesitas anak terutama remaja. Kedua orangtua obesitas memiliki prevalensi 70\%-80\% untuk memiliki anak obesitas. Sedangkan salah satu orangtua, ayah atau ibu saja, memberikan prevalensi 40\%-50\% untuk anaknya mengalami obesitas. Bagi orangtua yang tidak obesitas memiliki prevalensi $14 \%$ anak mengalami obesitas. ${ }^{8,9}$

Melalui data yang diperoleh, dapat dilihat bahwa dari tahun ke tahun prevalensi obesitas dunia semakin meningkat. Laporan riset kesehatan dasar tahun 2007-2013 mengenai meningkatnya angka obesitas remaja, juga didukung oleh tingginya kejadian remaja atau anak untuk mengalami obesitas ketika ada orangtuanya yang obesitas. ${ }^{5}$ Penelitian ini bertujuan untuk mengetahui hubungan orangtua yang obesitas dengan kecenderungan ikut sertanya remaja pada keluarga tersebut mengalami obesitas, khususnya pada anak sekolah menengah atas dibeberapa sekolah di Denpasar tahun 2015.

\section{BAHAN DAN METODE}

Penelitian ini merupakan penelitian observasional dengan studi potong lintang analitik. Peneliti mengumpulkan data untuk mencari hubungan antara obesitas orangtua dengan obesitas remaja di Denpasar, Bali. Penelitian dilakukan kepada siswa siswi remaja sekolah menengah atas di beberapa sekolah di Denpasar pada tahun 2015.

Populasidan Sampel peneliti-an diambil secara purposive sampling, dimana dipilih sampel yang menurut peneliti cukup bervariasi dan cocok untuk menginterpretasikan populasi target. Siswa siswi SMA Negeri 2 Denpasar, SMA Negeri 3 Denpasar, SMA Negeri 8 Denpasar, dan juga SMA Santo Yoseph Denpasar kelas X dan XI yang dipilih oleh peneliti menjadi lokasi pengumpulan data. Pengumpulan data dilakukan diantara tanggal 10 Agustus hingga 19 September $2015 .^{10}$

Besar sampel minimal peneliti dihitung mengunakan uji hipotesis terhadap 2 proporsi atau 2 kelompok indepeden. Melalui perhitungan rumus dan berdasarkan data pustaka penelitian sebelumnya, jumlah minimal sampel sebesar 83 orang. Jumlah minimal dikalikan dua dan ditambahkan $20 \%$ dari angka subjek minimal tersebut, guna menghindari terjadinya drop out peserta penelitian, sehingga jumlah sampel menjadi sebesar 199 orang.

Pengumpulan data dilakukan dengan penyebaran kuesioner di masing-masing sekolah, pada beberapa kelas yang telah ditentukan. Siswa-siswi diminta mengisi data pribadi mereka berupa nama, asal sekolah, jenis kelamin, umur, etnis, dan tempat tanggal lahir. Kemudian dilakukan pengukuran berat badan dan tinggi badan serta lingkar pinggang dan lingkar lengan atas siswa-siswi yang ada dalam kelas-kelas tersebut. Setelah pengukuran selesai, peneliti akan mengajarkan cara pengukuran lingkar pinggang dan lingkar lengan atas dengan mengunakan meteran kain. Setelah dipastikan bahwa siswasiswi sudah mengerti cara pengukuran, maka siswa-siswi diminta bantuannya untuk mengisi data orangtuanya. Data orangtua berupa nama, umur, etnis, dan tempat tanggal lahir, serta diminta kesediaan mereka untuk juga mengukur berat badan, tinggi badan, lingkar pinggang, serta lingkar lengan atas orangtua mereka, baik ayah maupun ibu. Setelah data terkumpul, peneliti akan menghitung indeks massa tubuh tiap-tiap respondennya.

Jenis data yang digunakan adalah data primer yang didapat ketika suatu penelitian itu berlangsung. Data dalam penelitian ini akan diperoleh dari pengisian kuesioner dan pengukuran yang sudah ada. Data yang telah terkumpul akan kemudian di analisis dengan mengunakan program statisik SPSS Statistics 21. Analisis yang akan digunakan adalah analisis univariat dan analisis bivariat berupa uji Chi-square.

\section{HASIL}

Total kuesioner yang diisi adalah 298 kuesioner, namun yang dapat dianalisis peneliti adalah 188 kuesioner (63,09\%). Sisanya 110 kuesioner $(36,91 \%)$ tidak dapat dipergunakan karena ketidaklengkapan dalam pengisian data.

Karakteristik daripada subjek penelitian dibagi menjadi karakteristik siswa-siswi, ayah, dah ibu. Tabel 1 menunjukkan bahwa mayoritas siswa-siswi yang menjadi responden adalah perempuan dengan jumlah 127 orang $(67,6 \%)$. Responden kebanyakan berumur $\leq 15$ tahun dengan jumlah 114 orang $(60,6 \%)$ dan bersuku Bali dengan jumlah 96 orang $(51,1 \%)$. Jumlah responden dari setiap sekolahnya cukup seimbang. Karakteristik status gizi responden menunjukkan rerata berat badan dan tinggi badan yaitu masing-masing $56 \mathrm{~kg}$ dan 161 $\mathrm{cm}$. Rerata indeks massa tubuh dan lingkar pinggang masih 
terbilang normal, dengan nilai secara berurutan 21,3 dan 74,3 $\mathrm{cm}$. Lingkar lengan atas juga menunjukkan angka rerata yang masih terbilang normal, 25,8 cm.

Melalui data yang didapatkan, siswa-siswi remaja di beberapa sekolah menengah atas di Denpasar yang obesitas pada tahun 2015 berjumlah 29 orang dari 188 orang yang diperoleh, dengan angka prevalensi 15,4\% dinilai berdasarkan dengan indeks massa tubuh dari siswa-siswi tersebut, yang telah diukur sebelumnya.

Tabel 1. Karakteristik Siswa-Siswi dari Beberapa Sekolah Menengah Atas

di Denpasar Pada Tahun 2015

\begin{tabular}{|c|c|c|c|}
\hline Variabel & n (\%) & Rerata & Jangkauan \\
\hline \multicolumn{4}{|l|}{ Siswa } \\
\hline \multicolumn{4}{|l|}{ Jenis Kelamin } \\
\hline Lelaki & $60(31,9)$ & - & - \\
\hline Perempuan & $127(67,6)$ & & \\
\hline \multicolumn{4}{|l|}{ Umur Siswa } \\
\hline$\leq 15$ tahun & $114(60,6)$ & 15,28 tahun & 14-17 tahun \\
\hline$>15$ tahun & $73(38,8)$ & & \\
\hline \multicolumn{4}{|l|}{ Asal Sekolah } \\
\hline SMA Negeri 2 Denpasar & $50(26,6)$ & & \\
\hline SMA Negeri 3 Denpasar & $44(23,4)$ & - & - \\
\hline SMA Negeri 8 Denpasar & $51(27,1)$ & & \\
\hline SMAK Santo Yoseph & $43(22,9)$ & & \\
\hline \multicolumn{4}{|l|}{ Dps } \\
\hline \multicolumn{4}{|l|}{ Etnis Siswa } \\
\hline Bali & $96(51,1)$ & & \\
\hline Betawi & $1(0,5)$ & & \\
\hline Flores & $1(0,5)$ & - & - \\
\hline Jawa & $10(5,3)$ & & \\
\hline Nusa Tenggara Timur & $1(0,5)$ & & \\
\hline Tionghua & $18(9,6)$ & & \\
\hline \multicolumn{4}{|l|}{ Berat Badan Siswa } \\
\hline$\leq 53 \mathrm{~kg}$ & $96(51,1)$ & $55,59 \mathrm{~kg}$ & $38-103 \mathrm{~kg}$ \\
\hline$>53 \mathrm{~kg}$ & $88(46,8)$ & & \\
\hline \multicolumn{4}{|l|}{ Tinggi Badan Siswa } \\
\hline$\leq 1,61 \mathrm{~m}$ & $94(50)$ & $1,61 \mathrm{~m}$ & $1,43-1,81 \mathrm{~m}$ \\
\hline$>1,61 \mathrm{~m}$ & $92(49,8)$ & & \\
\hline \multicolumn{4}{|l|}{ BMI Siswa } \\
\hline$<25$ & $150(79,8)$ & 21,3 & $14,1-34,8$ \\
\hline$\geq 25$ & $29(15,4)$ & & \\
\hline \multicolumn{4}{|l|}{ Lingkar Pinggang Siswa } \\
\hline$<90 \mathrm{~cm}$ & $52(41,3)$ & $76,5 \mathrm{~cm}$ & $60-100 \mathrm{~cm}$ \\
\hline$\geq 90 \mathrm{~cm}$ & $9(7,1)$ & & \\
\hline \multicolumn{4}{|l|}{ Lingkar Pinggang Siswi } \\
\hline$<80 \mathrm{~cm}$ & $104(82,5)$ & $73,4 \mathrm{~cm}$ & $62-102 \mathrm{~cm}$ \\
\hline$\geq 80 \mathrm{~cm}$ & $22(17,5)$ & & \\
\hline \multicolumn{4}{|l|}{ Lingkar Lengan Atas Siswa } \\
\hline$<32 \mathrm{~cm}$ & $174(92,6)$ & $25,8 \mathrm{~cm}$ & $19-43 \mathrm{~cm}$ \\
\hline$\geq 32 \mathrm{~cm}$ & $12(6,4)$ & & \\
\hline
\end{tabular}




\section{ARTIKEL ASLI}

Jurnal Penyakit Dalam Udayana

Udayana Journal of Internal Medicine

Print ISSN: 2580-2925

Volume 1, No 1: 2017

Online ISSN: $2580-2933$

Tabel 2. Karakteristik Ayah Siswa-Siswi dari Beberapa SMA di Denpasar Pada Tahun 2015

\begin{tabular}{|c|c|c|c|}
\hline Variabel & $\mathrm{n}(\%)$ & Rerata & Jangkauan \\
\hline \multicolumn{4}{|l|}{ Umur Ayah } \\
\hline$\leq 47$ tahun & $94(50)$ & 47,4 tahun & 36-60 tahun \\
\hline$>47$ tahun & $82(43,6)$ & & \\
\hline \multicolumn{4}{|l|}{ Etnis } \\
\hline Ambon & $1(0,5)$ & & \\
\hline Bali & $95(50,5)$ & & \\
\hline Betawi & $1(0,5)$ & & \\
\hline Flores & $1(0,5)$ & - & - \\
\hline India & $1(0,5)$ & & \\
\hline Jawa & $10(5,3)$ & & \\
\hline Nusa Tenggara Timur & $1(0,5)$ & & \\
\hline Tionghua & $17(9)$ & & \\
\hline \multicolumn{4}{|l|}{ Berat Badan Ayah } \\
\hline$\leq 70 \mathrm{~kg}$ & $101(53,7)$ & $72,08 \mathrm{~kg}$ & $45-110 \mathrm{~kg}$ \\
\hline$>70 \mathrm{~kg}$ & $87(46,3)$ & & \\
\hline \multicolumn{4}{|l|}{ Tinggi Badan Ayah } \\
\hline$\leq 1.7 \mathrm{~m}$ & $124(66)$ & $1,69 \mathrm{~m}$ & $1,55-1,89 \mathrm{~m}$ \\
\hline$>1.7 \mathrm{~m}$ & $64(34)$ & & \\
\hline \multicolumn{4}{|l|}{ BMI Ayah } \\
\hline$<25$ & $72(38,3)$ & 25,2 & $17,9-38,1$ \\
\hline$\geq 25$ & $93(49,5)$ & & \\
\hline \multicolumn{4}{|l|}{ Lingkar Pinggang Ayah } \\
\hline$<90 \mathrm{~cm}$ & $95(50,5)$ & $89 \mathrm{~cm}$ & $32-114 \mathrm{~cm}$ \\
\hline$\geq 90 \mathrm{~cm}$ & $92(48,9)$ & & \\
\hline \multicolumn{4}{|l|}{ Lingkar Lengan Atas Ayah } \\
\hline$<32 \mathrm{~cm}$ & $61(32,4)$ & $33,4 \mathrm{~cm}$ & $15-50 \mathrm{~cm}$ \\
\hline$\geq 32 \mathrm{~cm}$ & $109(58)$ & & \\
\hline
\end{tabular}

Tabel 3. Karakteristik Ibu Siswa-Siswi dari Beberapa SMA di Denpasar Pada Tahun 2015

\begin{tabular}{|c|c|c|c|}
\hline Variabel & $\mathbf{n}(\%)$ & Rerata & Jangkauan \\
\hline \multicolumn{4}{|l|}{ Umur Ibu } \\
\hline$\leq 44$ tahun & $88(46,8)$ & 44,3 tahun & 35-58 tahun \\
\hline$>44$ tahun & $86(45,7)$ & & \\
\hline \multicolumn{4}{|l|}{ Etnis } \\
\hline Bali & $94(50)$ & & \\
\hline Jawa & $13(6,9)$ & - & - \\
\hline Nusa Tenggara Timur & $1(0,5)$ & & \\
\hline Tionghua & $15(8)$ & & \\
\hline Waingapu & $1(0,5)$ & & \\
\hline \multicolumn{4}{|l|}{ Berat Badan Ibu } \\
\hline$\leq 60 \mathrm{~kg}$ & $111(59)$ & $61,3 \mathrm{~kg}$ & $45-86 \mathrm{~kg}$ \\
\hline$>60 \mathrm{~kg}$ & $77(41)$ & & \\
\hline \multicolumn{4}{|l|}{ Tinggi Badan Ibu } \\
\hline$\leq 1,59 \mathrm{~m}$ & $95(50,5)$ & $1,59 \mathrm{~m}$ & $1,45-1,78 \mathrm{~m}$ \\
\hline \multicolumn{4}{|l|}{ BMI Ibu } \\
\hline$<25$ & $98(52,1)$ & 24,1 & $17,7-35,6$ \\
\hline$\geq 25$ & $74(39,4)$ & & \\
\hline \multicolumn{4}{|l|}{ Lingkar Pinggang Ibu } \\
\hline$<80 \mathrm{~cm}$ & $71(37,8)$ & $82,8 \mathrm{~cm}$ & $37-114 \mathrm{~cm}$ \\
\hline $\begin{array}{l}\quad \geq 80 \mathrm{~cm} \\
\text { Lingkar Lengan Atas Ibu }\end{array}$ & $117(62,2)$ & & \\
\hline$<32 \mathrm{~cm}$ & $113(60,1)$ & $30,7 \mathrm{~cm}$ & $21-50 \mathrm{~cm}$ \\
\hline$\geq 32 \mathrm{~cm}$ & $62(33)$ & & \\
\hline
\end{tabular}


Tabel 4. Hubungan Antara Status Nutrisi Pada Orangtua dan Anak SMA di Denpasar pada tahun 2015

\begin{tabular}{|c|c|c|c|c|}
\hline & \multicolumn{4}{|c|}{ Anak } \\
\hline & Tidak Obesitas & Obesitas & $\begin{array}{c}\mathrm{RR} \text { (Relative } \\
\text { Ratio) }\end{array}$ & $\mathrm{P}$ \\
\hline \multicolumn{5}{|l|}{ Ayah } \\
\hline \multicolumn{5}{|l|}{ IMT } \\
\hline Tidak Obesitas & $84(88,4 \%)$ & $11(11,6 \%)$ & 0,598 & 0,140 \\
\hline Obesitas & $75(80,6 \%)$ & $18(19,4 \%)$ & & \\
\hline \multicolumn{5}{|l|}{ Lingkar Pinggang } \\
\hline Tidak Obesitas Sentral & $81(84,4 \%)$ & $15(15,6 \%)$ & 0,799 & 0,478 \\
\hline Obesitas Sentral & $74(80,4 \%)$ & $18(19,6 \%)$ & & \\
\hline \multicolumn{5}{|l|}{ IMT dan Lingkar Pinggang } \\
\hline Tidak Obesitas & $54(81,8 \%)$ & $12(18,2 \%)$ & 0,765 & 0,376 \\
\hline Obesitas & $93(76,2 \%)$ & $29(23,8 \%)$ & & \\
\hline \multicolumn{5}{|l|}{ IMT dan Lingkar Pinggang/ Lingkar } \\
\hline \multicolumn{5}{|l|}{ Lengan Atas } \\
\hline Tidak Obesitas & $91(79,8 \%)$ & $23(20,2 \%)$ & 0,829 & 0,501 \\
\hline Obesitas & $56(75,7 \%)$ & $18(24,3 \%)$ & & \\
\hline \multicolumn{5}{|l|}{ Ibu } \\
\hline \multicolumn{5}{|l|}{ IMT } \\
\hline Tidak Obesitas & $101(88,6 \%)$ & $13(11,4 \%)$ & 0,527 & 0,058 \\
\hline Obese & $58(78,4 \%)$ & $16(21,6 \%)$ & & \\
\hline \multicolumn{5}{|l|}{ Lingkar Pinggang } \\
\hline Tidak Obesitas Sentral & $63(88,7 \%)$ & $8(11,3 \%)$ & 0,527 & 0,078 \\
\hline Obesitas Sentral & $92(78,6 \%)$ & $25(21,4 \%)$ & & \\
\hline \multicolumn{5}{|l|}{ IMT dan Lingkar Pinggang } \\
\hline Tidak Obesitas & $50(82 \%)$ & $11(18 \%)$ & 0,763 & 0,385 \\
\hline Obesitas & $97(76,4 \%)$ & $30(23,6 \%)$ & & \\
\hline \multicolumn{5}{|l|}{ IMT dan Lingkar Pinggang/ Lingkar } \\
\hline \multicolumn{5}{|l|}{ Lengan Atas } \\
\hline Tidak Obesitas & $110(83,3 \%)$ & $22(16,7 \%)$ & 0,491 & 0,009 \\
\hline Obesitas & $37(66,1 \%)$ & $19(33,9 \%)$ & & \\
\hline \multicolumn{5}{|l|}{ Orangtua } \\
\hline \multicolumn{5}{|l|}{ IMT } \\
\hline Tidak Obesitas & $63(92,6 \%)$ & $5(7,4 \%)$ & & \\
\hline Salah Satu Orangtua Obesitas & $70(81,4 \%)$ & $16(18,6 \%)$ & 0,395 & 0,043 \\
\hline Kedua Orangtua Obesitas & $26(76,5 \%)$ & $8(23,5 \%)$ & 0,313 & 0,021 \\
\hline \multicolumn{5}{|l|}{ Lingkar Pinggang } \\
\hline Tidak Obesitas Sentral & $41(89,1 \%)$ & $5(10,9 \%)$ & & \\
\hline Salah Satu Orangtua Obesitas Sentral & $62(82,7 \%)$ & $13(17,3 \%)$ & 0,627 & 0,332 \\
\hline Kedua Orangtua Obesitas Sentral & $52(77,6 \%)$ & $15(22,4 \%)$ & 0,486 & 0,115 \\
\hline \multicolumn{5}{|l|}{ IMT dan Lingkar Pinggang } \\
\hline Tidak Obesitas & $22(84,6 \%)$ & $4(15,4 \%)$ & & \\
\hline Salah Satu Orangtua Obesitas & $60(80 \%)$ & $15(20 \%)$ & 0,769 & 0,604 \\
\hline Kedua Orangtua Obesitas & $65(74,7 \%)$ & $22(25,3 \%)$ & 0,608 & 0,292 \\
\hline \multicolumn{5}{|l|}{ IMT dan Lingkar Pinggang/Lingkar } \\
\hline \multicolumn{5}{|l|}{ Lengan Atas } \\
\hline Tidak Obesitas & $71(86,6 \%)$ & $11(13,4 \%)$ & & \\
\hline Salah Satu Orangtua Obesitas & $59(72 \%)$ & $23(28 \%)$ & 0,478 & 0,021 \\
\hline Kedua Orangtua Obesitas & $17(70,8 \%)$ & $7(29,2 \%)$ & 0,460 & 0,071 \\
\hline
\end{tabular}


Karakteristik ayah siswa-siswi ditunjukkan pada Tabel 2. Ayah responden kebanyakan berumur $\leq 47$ tahun, 94 orang (50\%), kebanyakan berasal dari suku Bali dengan jumlah 95 orang $(50,5 \%)$. Karakteristik status gizi ayah menjukkan rerata berat badan dan tinggi badan 72,09 kg dan $169 \mathrm{~cm}$ secara berurutan. Rerata indeks massa tubuh ayah responden adalah 25,2 yang tergolong obesitas tingkat I sesuai kriteria Asia-pasifik. Lingkar pinggang ayah responden memiliki angka yang masih terbilang normal namun cenderung tinggi, $89 \mathrm{~cm}$. Sedangkan angka lingkar lengan atas ayah responden menunjukkan rerata 33,4 cm yang tergolong obesitas. Dilihat dari indeks massa tubuhnya, ayah yang obesitas tahun 2015 berjumlah 93 orang, prevalensi 49,5\%.

Karakteristik ibu responden yang ditunjukkan dalam Tabel 3. Kebanyakan ibu memiliki umur berkisar pada umur $\leq 44$ tahun, yang berjumlah 88 orang ibu $(46,8 \%)$. Ibu dari responden kebanyakan bersuku Bali dengan jumlah 94 orang (50\%). Karakteristik status gizi dari ibu responden menujukkan rerata berat badan dan tinggi badan $61,3 \mathrm{~kg}$ dan $159 \mathrm{~cm}$ secara berurutan. Indeks massa tubuh dari ibu masih termasuk kriteria berisiko untuk obesitas pada kriteria Asiapasifik, dengan angka 24,1. Lingkar pinggang ibu memiliki rerata $82,8 \mathrm{~cm}$, termasuk kedalam kriteria obesitas sentral. Lingkar lengan daripada ibu memiliki angka rerata $30,7 \mathrm{~cm}$ yang termasuk dalam kriteria obesitas. Berdasarkan dengan indeks massa tubuh, ibu yang mengalami obesitas di Denpasar pada tahun 2015 berjumlah 74 orang, dengan angka prevalensi $39,4 \%$.

Melalui uji chi-square, didapatkan hasil seperti ditunjukkan pada Tabel 4. Data menunjukkan bahwa dari seluruh variabel status gizi pada ayah, nilai relative risk (RR) antara tidak obesitas dengan yang obesitas memiliki angka mendekati 0 atau memiliki risiko yang lebih kecil. Namun, semua variabel menunjukkan hubungan yang tidak signifikan.

Pada seluruh variabel status gizi ibu, nilai relative risk tidak obesitas dengan yang obesitas memiliki angka yang mendekati 0 , yang menandakan risiko yang lebih kecil (Tabel 4). Dua variabel menunjukkan adanya hubungan. Status nutrisi pada ibu berdasarkan indeks massa tubuh dan juga indeks massa tubuh dengan lingkar pinggang/ lingkar lengan atas terhadap obesitas pada anak. Namun pada status gizi ibu berdasarkan indeks massa tubuh memiliki data yang kurang signifikan. Hal ini dapat terjadi dikarenakan masih kurangnya jumlah sampel yang dibutuhkan dalam penelitian, sehingga nilai $p$ masih kurang cukup untuk mencapai kesignifikanan.

Pada seluruh variabel status gizi dari jumlah orangtua yang obesitas, angka relative risk antara orangtua yang tidak obesitas dengan salah satu orangtua obesitas maupun orangtua tidak obesitas dengan yang kedua orangtua obesitas mendekati 0 , yang menandakan risiko yang lebih kecil. Variabel lingkar pinggang dan indeks massa tubuh dengan lingkar pinggang, baik pada orangtua tidak obesitas dibandingkan dengan satu orangtua obesitas maupun kedua orangtua obesitas menunjukkan hasil yang tidak signifikan. Signifikansi ditunjukan oleh status nutrisi orangtua berdasarkan indeks massa tubuh baik pada satu orangtua obesitas maupun dua orangtua obesitas.

\section{PEMBAHASAN}

Studi ini menunjukkan bahwa prevalensi obesitas yang ada pada orangtua berdasarkan indeks massa tubuh adalah 40,96\%, dibagi menjadi ayah dan ibu di Denpasar pada tahun 2015. Dilihat dari indeks massa tubuhnya, ayah yang obesitas tahun 2015 berjumlah 93 orang, prevalensi 49,5\%. Angka lingkar lengan atas ayah responden menunjukkan rerata $33,4 \mathrm{~cm}$ yang tergolong obesitas menurut kriteria dari british association for parenteral and enteral nutrition (BAPEN).,11,12 Sedangkan untuk prevalensi obesitas ibu adalah 39,4\%. Lingkar pinggang ibu memiliki rerata $82,8 \mathrm{~cm}$, termasuk kedalam kriteria obesitas sentral menurut kriteria Asiapasifik. Lingkar lengan daripada ibu memiliki angka rerata $30,7 \mathrm{~cm}$ yang termasuk dalam kriteria obesitas menurut british association of parenteral and enteral nutrition., ${ }^{2,11,12} \mathrm{Hal}$ ini menandakan masih banyaknya orangtua di Denpasar dengan status nutrisi belum terjaga dengan baik.

Pada anak, prevalensi obesitas juga tinggi yaitu 15,4\%. Anak terbagi menurut jenis kelaminnya, lelaki obesitas $6,9 \%$ dan perempuan $8,5 \%$. Hal ini dapat meningkat di hari kedepannya jika tidak diatasi dengan tepat. Status gizi orangtua yang terbukti dalam studi memiliki hubungan dengan obesitas remaja di Denpasar dijumpai pada ibu yang berhubungan dengan indeks massa tubuh ibu dan indeks massa tubuh ibu dengan lingkar pinggang/lingkar lengan atas, nilai $p$ mendekati dan lebih kecil dari 0,05. Selain itu, status gizi orangtua, dalam hal ini jumlah orangtua obesitas yang ditinjau dari indeks massa tubuhnya menunjukkan hubungan status gizi orangtua terhadap terjadinya obesitas pada anak remaja sekolah menengah atas di Denpasar.

Prevalensi obesitas orang dewasa dibandingkan dengan studi di Amerika menurut national institute of health (NIH) melalui national institute of diabetes and digestive and kidney diseases (NIDDKD) 2012, ditemukan bahwa tahun 2009-2010 terdapat 35,7\% orang dewasa obesitas. Terdapat angka prevalensi obesitas yang sama baik pada lelaki maupun perempuan yaitu 36\%. Sedangkan tahun 2011-2012 di Amerika, 35,1\% orang dewasa obesitas dimana pada lelaki $33,7 \%$ dan perempuan $36,5 \%$. Prevalensi orang dewasa mengalami obesitas di California tahun 2010 memiliki angka 23,8\%, meningkat pada 2011 menjadi $24,2 \%$, dan pada 2012 menjadi $25,4 \%$. Lelaki dan perempuan berdasarkan sukunya, dimana pada suku Asia di California, lelaki memiliki prevalensi 15,9\% dan perempuan 8,8\%. Prevalensi obesitas di California 
tergolong tinggi, namun masih lebih rendah dibandingkan Denpasar yang ditemukan dalam studi ini. Dalam data yang di kumpulkan oleh riset kesehatan dasar 2013, prevalensi obesitas di Indonesia adalah 15.4\%, dari antaranya lelaki memiliki prevalensi $19.7 \%$ dan perempuan $32.9 \%$. Melalui penelitian yang lain didapatkan bahwa di Bali pada tahun 2013 ditemukan prevalensi obesitas diatas 30\%, dimana lelaki hampir 30\% dan perempuan hampir 30\% juga. Prevalensi Bali menunjukkan angka obesitas tinggi pada orangtua atau dewasa. ${ }^{1,5,13,14}$

Prevalensi obesitas anak menurut national institute of diabetes and digestive and kidney diseases untuk remaja 16,9\%, dimana berdasarkan umur 12-19 tahun prevalensinya 18,4\%, lelaki prevalensinya $18,6 \%$ dan perempuan $15 \%$, pada tahun 2009-2010. Tahun 2011-2012 di Amerika pada usia 1219 tahun, prevalensi obesitas 20,5\%, pada lelaki 20,3\% dan perempuan $20,7 \%$. Prevalensi di California untuk anak remaja umur 5-19 tahun di tahun 2008 adalah 22,8\%, tahun 2009 adalah $23,1 \%$, sedangkan pada tahun 2010 meningkat menjadi 23,3\%. Menurut riset kesehatan dasar 2013, anak remaja berumur 13-15 tahun memiliki prevalensi obesitas 2,5\%, pada umur 16-18 tahun berprevalensi 1,6\%, di Indonesia. Sedangkan di Bali prevalensi obesitas mencapai $12 \%$ pada umur 13-15 tahun, umur 16-18 tahun memiliki prevalensi 10\%. Prevalensi obesitas pada anak di Amerika dan California tergolong tinggi, begitu juga di Bali yang memiliki angka prevalensi yang tinggi. $1,1,13,14$

Hubungan status gizi ibu berdasarkan indeks massa tubuh memiliki hasil data yang signifikan terhadap status gizi pada anak. Hubungan status gizi pada jumlah orangtua berdasarkan indeks massa tubuh juga memiliki hasil signifikan terhadap status gizi anak. Sedangkan dilihat dari studi lainnya di China, digunakan 5.041 orang anak dan remaja. Berdasarkan indeks massa tubuh, pada orangtua tidak obesitas terdapat prevalensi anak obesitas sebesar 6,07\%. Salah satu orangtua mengalami obesitas, obesitas pada anak meningkat menjadi $11,82 \%$. Sedangkan, pada kedua orangtua mengalami obesitas, prevalensi anak meningkat menjadi 21,95\%. Jadi pada kedua orangtua obesitas, dalam penelitian mereka memiliki risiko 3,62 kali dibandingkan dengan orangtua sehat. Obesitas orangtua dalam studi ini dinyatakan memiliki pengaruh terhadap obesitas anak. ${ }^{15}$

Studi ini tidaklah terlepas dari kelemahan. Dipengaruhinya nilai $p$ oleh jumlah dari sampel, sehingga semakin besarnya jumlah sampel akan menurunkan nilai $p$ sehingga akan semakin signifikan, karena kesalahan akan menjadi semakin kecil terlihat pada data yang jumlahnya meningkat. ${ }^{16}$ Selain itu, hasil pengolahan data statistik terkadang tidak sama dengan teori, memunculkan hasil pengolahan data yang tidak signifikan. Pengisian data pada kuesioner bisa diisi dengan kurang tepat, tidak sesuai dengan permintaan dalam kuesioner. Prosedur pengukuran orangtua siswa yang kurang tepat sehingga terkadang terdapat data yang tidak dapat dipakai karena tidak sesuai. Penelitian ini tidak melihat faktor-faktor perancu lainnya, sehingga perlu penelitian yang lebih lengkap di masa mendatang.

\section{SIMPULAN}

Melalui hasil studi yang diperoleh, didapatkan prevalensi obesitas pada orangtua di Denpasar tahun 2015 berdasarkan indeks massa tubuh yang masih tinggi. Prevalensi obesitas pada anak remaja sekolah menengah atas di Denpasar tahun 2015 berdasarkan indeks massa tubuh juga masih tinggi. Obesitas ibu menunjukkan hubungan yang signifikan terhadap obesitas anak, terlebih lagi status gizi dari jumlah orangtua berdasarkan indeks massa tubuh terhadap anak. Status gizi orangtua berdasarkan jumlah orangtua berdasarkan indeks massa tubuh menunjukkan adanya hubungan antara obesitas orangtua terhadap anak remaja sekolah menengah atas di Denpasar tahun 2015, dan hubungan tersebut signifikan.

\section{DAFTAR PUSTAKA}

1. The NHS Information Centre, Lifestyles Statistics. Statistics on obesity, physical activity and diet: England, 2012. England: National Health Statistics (NHS); 2012.

2. Lim JU, Lee JH, Kim JS, dkk. Comparison of World Health Organization and Asia-Pacific body mass index classifications in COPD patients. Dove Press journal: Int J Chron Obstruct Pulmon Dis. 2017;12:2465-75.

3. WHO Team. World Health Statistics (WHS) 2012: Noncommunicable Diseases: a Major Health Challenge of the $21^{\text {st }}$ Century. France: World Health Organization (WHO); 2012.

4. OECD Team. Economic, Environmental, and Social Statistics: Overweight and Obesity. Organization of Economic Co-operation and Development (OECD) Factbook: 2013.

5. RISKESDAS Team. RISET KESEHATAN DASAR 2013. Jakarta: Kementrian Kesehatan Indonesia; 2013.

6. RISKESDAS Team. RISET KESEHATAN DASAR 2007. Jakarta: Kementrian Kesehatan Indonesia; 2008.

7. Rossouw HA, Grant CC Viljoen M. Overweight and obesity in children and adolescents: The South African problem. South African Journal Science. S Afr J Sci. 2012;108(5/6):1-7.

8. Permatasari IRI, Mayulu N, Hamel R. Analisa riwayat orang tua sebagai faktor resiko obesitas pada anak SD di Kota Manado. Ejournal keperawatan (e-Kp). 2013;1(1):17.

9. Sartika RAD. Faktor risiko obesitas pada anak 5-15 tahun di Indonesia. Makara, Kesehatan. 2011;15(1):37-43. 


\section{ARTIKEL ASLI}

Jurnal Penyakit Dalam Udayana

Udayana Journal of Internal Medicine

Volume 1, No 1: 2017

Print ISSN: 2580-2925

Online ISSN: 2580-2933

10. Sastroasmoro S, Ismael S. Dasar-dasar Metodologi Penelitian Klinis. Edisi 4. Jakarta: Sagung Seto; 2011. h. 104-29.

11. WHO Team. Waist Circumference and Waist-Hip Ratio: Report of a WHO Expert Consultation. Geneva: World Health Organization (WHO); 2008. h. 20.

12. Malnutrition Action Group. The 'MUST' Explanatory Booklet: a Guide to the 'Malnutrition Universal Screening Tool'('MUST') for Adult. British Association for Parenteral and Enteral Nutrition (BAPEN): 2011. h. 16.

13. CDPH Team. Obesity in California: The Weight of the State, 2000-2012. California: California Department of Public Health; 2014. h. 10-7.

14. Ogden CL, Carroll MD, Kit BK, dkk. Prevalence of childhood and adult obesity in the United States, 20112012. JAMA. 2014;311(8):806-14.

15. Jiang MH, Yang Y, Guo XF, dkk. Association between child and adolescent obesity and parental weight status: a cross-sectional study from rural North China.J Int Med Res. 2013;41(4):1326-32.

16. Turcios RAS. Demystification of the significance of $p$ in statistical tests. Rev Mex Cardiol. 2015;26(1): 56-8.

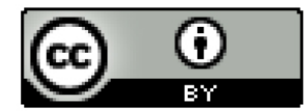

This work is licensed under a Creative Commons Attribution 4.0 International License. 